\title{
THE BEGINNING OF UKRMAN - A FIGHTER AGAINST THE EVIL AND THE CORONAVIRUS
}

\author{
Anja Lange (a) \\ (a) Kyrgyz-German Institute of Applied Informatics "INAI". Bishkek, Kyrgyz Republic. \\ Email: anja.dsc[at]gmail.com
}

\begin{abstract}
Comics have a big task in Ukraine: Through them nation is built, historical events are discussed and identity is constructed. In 2018 Ukraine's first superhero was introduced: UKRMAN. In the past, the Cossacks have been the heroes of Ukraine and were also portrayed in various comics. But in a time when the national integrity of Ukraine is tested through an armed conflict in the East, a new superhero is sorely needed. The comic combines the past (Communist era with the Chernobyl nuclear accident) and the present of Ukraine in a unique way. The article will show why the implementation of a new superhero (especially his look, his behavior and the background of the plot) is necessary for Ukrainian nation building. The symbols UKRMAN uses tend to unify the country by giving it a superhero everybody can identify him- or herself with. The message of the comic is that someone does not have to wear a cape to be depicted as a hero. The comic as the beginning of a project with videos and merchandise is the first one of that kind in Ukraine.
\end{abstract}

\section{Keywords}

Ukraine; Revolution; War; Superhero; Super Powers; Chernobyl Nuclear Accident; Captain America; Nation Building; Identity; Ukrainian Comics

This work is licensed under a Creative Commons «Attribution» 4.0 International License. 


\title{
НАЧАЛО УКРМЕНА - БОРЕЦ ПРОТИВ ЗЛА И КОРОНАВИРУСА
}

\author{
Ланге Аня (a) \\ (а) Кыргызско-Германский институт прикладной информатики. Бишкек, Кыргызстан. \\ Email: anja.dsc[at]gmail.com
}

\section{Аннотация}

У комиксов большая задача в Украине: с их помощью строится нация, обсуждаются исторические события, выстраивается идентичность. В 2018 году в Украине появился первый супергерой: Укрмен. В прошлом казаки были героями Украины и изображались в различных комиксах. Но в то время, когда национальная целостность Украины проверяется вооруженным конфиликтом на Востоке, необходимость в новом супергерое ощущается остро. В комиксе уникальным образом сочетаются прошлое (коммунистическая эпоха с Чернобыльской атомной аварией) и настоящее Украины. В статье будет показано, почему появление нового супергероя ( с его внешним видом, поведением и фоном сюжета) так необходимо для строительства украинской нации. Символы, которые использует Укрмен, направлены на объединение страны, давая ей супергероя, с которым каждый может идентифицировать себя. Послание комикса заключается в том, что человеку не обязательно носить плащ, чтобы быть героем. Комикс, будучи основой проекта с видеороликами и сувенирами, является первым подобным явлением в Украине.

\section{Ключевые слова}

Украина; Революция; Война; Супергерой; Супердержавы; Авария на Чернобыльской атомной электростанции; Капитан Америка; Государственное строительство; Идентичность; Украинские комиксы

Это произведение доступно по лицензии Creative Commons «Attribution» («Атрибуция») 4.0 Всемирная 


\section{INTRODUCTION}

In Ukraine the comic industry is still in its infancy. Recently, the comic market began to develop, more and more comics are translated into Ukrainian and are published in Ukraine. Ukraine has colorful heroes in its comics but until 2018, there has never been a western comic style superhero. Now, UKRMAN is published and marks a turning point of Ukrainian comic industry. There has been a huge marketing campaign and many reviews have been made popularizing the comic genre in the whole country. The comic also seems to be controversial, yet it refers to the recent events in Ukraine, i.e. the Maidan revolution and the armed conflict in the Eastern part of Ukraine.

This article will show the discourse about the comic, explain some key points of Ukrainian comic book industry and show the main motifs of the comic. Even though the comic plays in Kyiv and is not directly referring to the current situation in Ukraine, there are some strong references to it. The article will show how the nation building process is combined with comics and which role does UKRMAN play. The question will be answered why an Ukrainian superhero was sorely needed in the 21st century. What are his tasks? How is he portrayed? What is the message of the comic? Those questions will be answered in this article.

\section{INFORMATION ABOUT THE COMIC}

Ukraine has a new superhero: UKRMAN. On the cover of the first issue ("The Beginning" - "Pochatok") he is standing in a yellow-blue suit in the city center of Kyiv, the capital of Ukraine. The first issue of UKRMAN is a small book of 64 pages and was published in 2018 by the publishing House MOTHERTONGUE ("Ridna Mova") in Kyiv. The comic series of the publishing house is called "FLAT Company". "Riudna Mova" is also publishing American comics in Ukrainian. The comic is the first superhero comics of Ukraine. Anatoliy Tyahur, one of the authors of UKRMAN, announced the project in 2014 under the title "UKRMAN - is You!" The project was created to encourage and inspire people to be educated, polite, fair, brave, courageous, help others, involve people in a healthy lifestyle (State Intellectual Property Service of Ukraine Bulletin, Nr. 55 080). On the official homepage there is a promotion video about the comic and the comic also has an official YouTube channel. Though the first issues is called "The Beginning" until now there is no sequel announced. The comic is a softcover unusual for Ukrainian comics, most of them are hardcover books. 


\section{SUMMARY OF THE FIRST ISSUE OF THE COMIC}

UKRMAN - THE BEGINNING is the first issue of the new Superhero coming from Ukraine. But UKRMAN is not an origin story of a superhero. We don't see how the young man becomes a superhero, he already is a hero in the comic (and also well known by the society). The comic introduces UKRMAN as a young man being a student at the Chemical Institute of Kyiv. His name is Bohdan Belyi, he is shown with his Friends Zlata and Yurii, but only Yurii knows about his secret identity. Zlata, a girl with red hair, is secretly in love with UKRMAN, she draws him in the lessons and at home. Also, she seems to have extrasensory powers because she sees a later-on-fight of UKRMAN.

The comic starts with a brief introduction of the situation: Due to the nuclear accident in Chernobyl in 1986 a huge concentration of nuclear material was exposed and caused mutations in the human DNA. A rapid reaction force called " 86 " is built and has the task to protect the civilization against the evil mutants. The evil mutants already caught by the special force " 86 " are held captured in a secret prison specially made for those mutants.

The next panels show the secret laboratory of Dr. Khimikata ("Chemical"). He does experiments with Plutonium on human beings. He seems to cause the mutations having captured a healthy young man he wants to inject Plutonium to start mutations. His Plutonium came to an end and he sends a huge mutant named Buice (he looks similar like "The Thing" of Fantastic 4 or "Doomsday") to steal more Plutonium. The evil mutant robs the vehicle with the Plutonium, Bohdan sees this on television and suits up to become UKRMAN and fights the evil mutant Buice.

A small flashback shows how Bohdan stepped up for the first time (without a cape and a suit). He rescued the son of his Chemical professor. This small boy dies, before his death he gives Bohdan a sheet of paper where he was drawing the superhero and he wrote: "YOU ARE UKRMAN!" The same guy who killed the small boy is now the mutant who steals the Plutonium. UKRMAN fights the evil mutant and the special force is arresting him. The friend of Bohdan, Yurii, who also studies chemistry, took a blood sample of the mutant and finds out that this much radiation could not come from the nuclear accident. In the end, Doktor Chemical is shown screaming "UKRMAN, this is just the beginning!". Zlata once again draws UKRMAN but with herself as the hero. That could be a forecast to sequels with Zlata as the hero. 


\section{THE DISCOURSE ABOUT THE COMIC UKRMAN}

The following chapter tends to summarize some of the comments about the published graphic novel. The echo by the media was a strong one, the comic was widely reviewed. The Blogger Myron calls UKRMAN not a graphic novel but an ordinary comic: It has a superhero, a super villain, dynamical action scenes, mutants, drama and so on (Myron, 2018). With no sense of humor and one-sided personage, Pitnyk and Pitnyk say that the comic to be not developed enough. Reyns (2018) states that the money of the marketing campaign would have been invested in a better way in the plot. It will be shown later that the plot of the comic is often criticized by the audience. The Internet bookstore Yakaboo calls UKRMAN "a post-apocalyptic action saga for saving the Ukrainian capital" (Yakaboo, 2019). The alternative reality and the question what could have happen after the Chernobyl nuclear accident took place are some of the main questions of the comic. The obvious references to the symbols of Ukraine was also a point many critics noticed. The name and portray of UKRMAN includes obviously the absolute idea of a national hero (Pitnyk \& Pitnyk, 2019). Reyns states that even without garlic and horylka, typical entities picked for Ukraine, the comic shows a modern portray of Ukraine (Reyns, 2018). As we will see later, the Ukrainian symbols and entities are not always depicted as positive.

One critical point has been the similarity between the American comics and UKRMAN. Myron criticizes that UKRMAN almost looks like the small brother of Steve Rogers, he also has superpowers and even the way he talks is inspired by Captain America (Myron, 2018). The comparison between UKRMAN and Captain America will also play a role later, some other critics also pointed out that parallel. His superpowers are somehow not specified, he seems to be super strong, but there is not a special introduction of his super powers (Reyns, 2018) which leaves the reader puzzled. Most introductions of super heroes begin with an origin story where the background and the super powers are introduced.

Another point of critique is the lack of originality. The plot twists end without even beginning. Despite the large volume and good printing for both Ukrainian comics, Ukrman's adventures significantly lack originality (Pitnyk \& Pitnyk, 2019). Pitnyk and Pitnyk state that the background story of the Chernobyl accident to be the reason for mutations is not very creative.

The whole appearance of the comic is widely reviewed very positive: The book is not very thick but it is said to be stable, the paper has a good quality and the drawings and the whole layout looks very professional (Myron, 2018; Reyns, 2018; Pitynk \& Pitynk, 2019). 


\section{THE SUPERHERO IN THE UKRAINIAN LITERATURE}

First of all, the term "Superhero" should be defined to make sure what we are talking about. A superhero "is a figure that touches centrally on the likely future of humans" (Rosenberg \& MacFarland Coogan, 2013, p. XVIII). A superhero is a person "whose extraordinary or 'superhuman' powers are often displayed in a fight against crime and assorted villains, who in turn often display superhuman abilities" (Britannica, 2017). The comic book industry "has built up its own lively and heuristic critical discourse (...)" (Reynolds, 1992, p. 7). Reynolds (loc. cit) also states that superheroes are a "body of contemporary mythology". The superhuman aspect is very strong: Mostly, superheroes have huge power or ability that they gained by accident or from extraterrestrial material. When we look at the just given definition it becomes obvious that until 2018, there has not been in Ukraine such a person like a superhero. But Ukraine had other heroes in comics that will be shown in the following paragraph.

In Ukraine comics are still depicted as a medium for children (Lange, 2017, p. 160). Comics and graphic Novels are winning prices for "The best children's book" (as did Daohopak in 2012), there is not yet a literature price just for comics, therefore they are put in the children's corner). A wide stereotype about comics could be put into the following words: "Stories told with pictures and words cannot be approached seriously and are therefore good only for children « (Mburianyk, 2013).

Often in the beginning of the comics there is an introduction for the reader how to read the comic (as in Daohopak, Prasolov, Chebykin, Kolov, 2012 , p. 6). The printed UKRMAN comic has no such introduction, probably because there have been numerous publications of comics in the last years and the editors assume that the audience knows how to read a comic. The above given information that comics are just for children can also be seen at the homepage of UKRMAN: There the target group of the superhero comic are introduced: Children, teenagers and adults:

\section{Кому буде цікавий комікс}
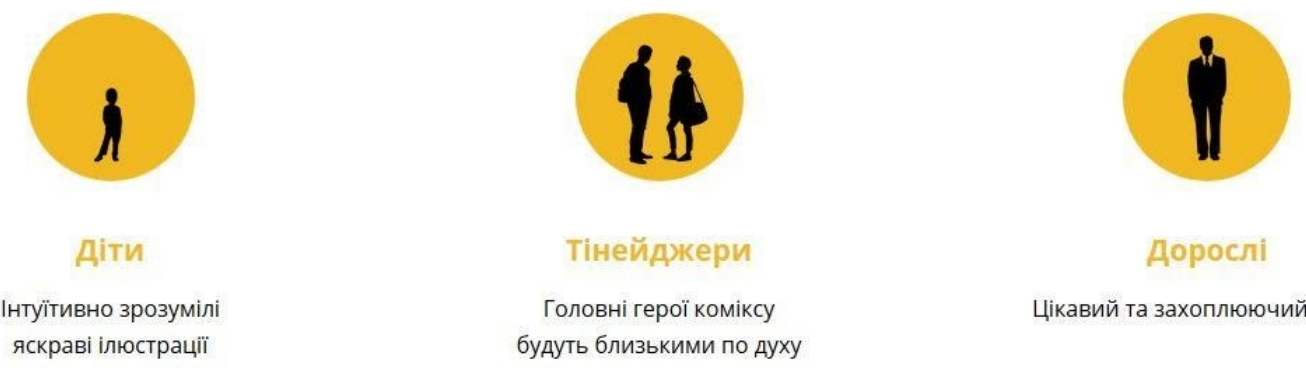

Дорослі

Цікавий та захоплюючий сюжет

Fig. 1. The target group of the comic. https://ukrman.ua $[26.08 .2020]^{1}$ 
Ukrainians went through all possible upheavals of the twentieth century without the participation of superheroes (Kvitka, 2019). At least there have been comics in Ukrainian literature. M. Burianyk gives an overview of the history of the Ukrainian comic. He states: "It is difficult to understand whether those examples have ever been published or are just fan translations available only on the internet" (M. Burianyk, 2015). Comic artist Ihor Barnko states that in the Soviet Union there have been no comics at all (Gavrishova, 2015). That is not entirely true. There have been comics but they have lived in the shadow. As the first comic of Ukraine is depicted "Chornoknyzhnyk z chornohory" (The Warlock from Montenegro) published by Yaroslav Vilshenko in 1921. This comic was republished in 2016. It contained patriotic elements showing the country of Ukraine in the person of a woman at the end of the comic (Sodomora, 2016). After the first comic of Ukraine, comic fans had to wait almost until the independence of the country to read the next published comic. In 1990 "Shovkova Derzhava" (Silk State) was published. After the Independence of Ukraine, many more comics were issued. Uncomics, an Ukrainian project which aims to make Ukrainian and international comics more popular to Ukrainian auditory, also finds the Ukrainian superhero in that time: The Cossacks. Buiviter, a comic about a legendary Ukrainian Cossack, became popular in 1995 (Uncomics, 2019). "The Ukrainian Cossack has come to symbolize Ukraine's ethnic image, much like the medieval knight of Western Europe or the Samurai of Japan" (Matychak, 2019). The Ukrainian Western hero and later superhero was the Cossack. That can also be underlined with historical facts: The Zaporozhian Cossacks are depicted to be the first building a purely Ukrainian society (Matychak, 2019). Therefore, the Cossack myth is still very important for the young nation of Ukraine. A Cossack battalion also has been present at the Maidan revolution in Kyiv. The Cossacks are also motifs in later comics like "Daohopak" (2013 and still ongoing, 3 issues so far). In 2015, "Ukrayinski superheroyi" (Ukrainian superhero) were published, a comic where Cossacks were fighting during the armed conflict in the East of Ukraine. Here, the message was: Ukrainian superheroes: That is the Kobzar [the musical instrument of the Cossacks), dill, Cyborgs and faith (Lvivskyi Portal, 2015).

Furthermore in 2013 there was published a comic about the "History of the Independent Ukraine", in 2016 the "Khroniky Aptauna" (Uptown Chronicles) were issued, the topic of this comic is the corruption in

1 "Children will intuitive understand the colorful illustrations. Teenagers: The main hero will be close fort hem because he is in the same age. Adults: Interesting and entertaining topic." [Translation by A.L.] 
Ukraine. 2017 "Volya" (The Will) was issued showing an alternative history of Ukraine in 1918. In 2020 the graphic novel "Kiberkray" (Cyberend) shows an alternative history of the 80s of Ukraine. The War in the Eastern part of Ukraine was the topic of the comics "Kiborhy" (Cyborgs) published in 2018. Here, the defenders of the airport of Donetsk are shown. In 2020 "Istoriya z Maydanu" - History of the Maidan was published showing the events of the revolution in 2014 in Kyiv.

Besides the presented comics, also Science-Fiction work does exist ("Son" - The Dream, "Svit 912" - The World 912 and "Sarcophagus"). But it is obvious that some comics do have a special function in Ukraine:

- They create identity by showing past or present events and historical symbols and personage

- They accentuate moments of the Ukrainian past that are still relevant for the present day, like Cossacks, the first Ukrainian nation, the revolution of dignity in 2014 bringing those events into the public discourse.

- They deal with the concept of Ukrainian identity, nation and the statehood of Ukraine, also (in present days) with the defense of that nation. In the past the Cossacks were building and defending the Ukrainian nation, nowadays, the soldiers in the Eastern part of Ukraine do that job.

The following quote seems to be a good summary to the above said:

Comics became yet another platform for discussion (Pitnyk \& Pitnyk, 2019). Especially after the events of 2014 patriotic comics were published. The heroism of 2014 stimulated creativity (Radio Svoboda, 2018). Numerous books, poems and novels were published about the Maidan-revolution. Ukrainian language became much more important and the symbols of Ukraine are omnipresent in Ukraine. That leads to yet another important fact: The developing of the comic book industry in Ukraine. Not only there are published much more comics in Ukrainian, but also foreign comics, especially American ones, are translated and published in Ukrainian (Radio Svoboda, 2018). Yet 10 years ago the only comics that could be bought in Ukraine were the small-scale Ukrainian ones and some translated in Russian. The translational industry also discovered their interest for comics recently.

\section{THE MESSAGE OF UKRMAN}

In 2018, a new superhero joined Ukrainian comics: Not Cossacks or soldiers, but an ordinary student who is stepping up to defend evil. In the comic, Bohdan says remarkable words: "To do good deeds, you don't need 
a costume" (Levchenko \& Tyahur, 2018, p. 12). In the line of the previous comics UKRMAN stands out: He seems to have special abilities due to the nuclear catastrophe. But the message behind the comic is clear: Everybody could be UKRMAN. Everybody could do good deeds; you don't need to be superhero. To underline that, Bohdan is shown as a good man, he lives in a small flat with his dog. He is shown as a good student and a kind person who has friends and is helping other people. Especially the "birth hour of UKRMAN", the car accident of the Chemical professor when Bohdan rescues the son from being taken by the evil mutant. He steps up to make a difference, he becomes an inspiration for other people. It is not clear whether Bohdan already had his super powers already during the car accident. But the sheer fact that he is helping the professor and avoids the kidnapping of the son makes the message effective.

This message is repeated several times in the many media channels of UKRMAN: The official Facebook page of UKRMAN states the message of the comic: In Ukraine there are numerous people that could be called superhero! (Facebook UKRMAN, 2020) Also the marketing video on You Tube contains this message.

Why put such a message in a comic book? What consequences could this message have? Romagnoli and Pagnucci (2013, p. 81) state that a message laid in comics can be very powerful. They refer to the Superman comics in the late 30s. At that time, the comic was also part of a radio show where the image of him flying through the city with his billowing cape was introduced. "Superman lets us believe that a man can fly" (Romagnoli \& Pagnucci, loc. cit.). A message transported by media (that could be a printed comic book or a radio broadcast) can be very powerful to people. The message of UKRMAN, transported in the comic, in the marketing announcement through the website and Facebook and part of the project initiated by the authors, could be powerful to especially young readers that are the target group of the comic. After the Maidan revolution it is every single Ukrainian needed to re-build the nation.

The message of the comic was discussed above: You don't need to wear a costume to be a hero. Myron (2018) criticizes that stereotypical phrase. She says that for sure no one is talking like that. The moral of the comics is shown too obvious in her meaning.

\section{A SUPERHERO - A WESTERN PHENOMENON?}

We took a close look at the history of the Ukrainian comics and we have the impression that there never have been superheroes in Ukrainian comics. Did Ukraine never need a superhero (but today does)? Is the con- 
cept of a superhero a typical Western entity? Does Eastern Europe not need a superhero?

Superheroes are nowadays very present at cinemas all over the world. The Dark Knight Trilogy by Christopher Nolan is depicted as a very important moment in the superhero genre. "It was the turning point in western cinema and ushered in what is now referred to as the Age of Superheroes" (accentuation by the author; Singh, 2017). Eastern Europe definitely takes part in that, in all cinemas of Ukraine the Western superhero movies were shown.

"The superhero genre has moved into the position held by the Western genre for most of the 20th century, when it served as a useful metaphorical way of discussing immigration, Americanization, urbanization, American identity, changing concepts of race and gender, individualism [...]" (Rosenberg \& MacFarland Coogan, 2013, p. XVII). Eastern Europe never had the genre of Western. But today it has superheroes. How did that happen?

It seems to be important to have a closer look to the structure of the societies of the West and the East. In the East (one example could be the Soviet System or today's China) societies are built on the collective nature of social obligation, while other societies, mostly Western ones, are much more individualistic (Markus \& Kitayama, 1990). The Cossacks were always groups of people. The leaders, the so-called Hetman, is a single man, but he has his horde behind him. On the contrary, superheroes are mostly single people with superpowers who are rescuing the world. Of course, there always have been groups of superheroes (like The Avengers of the Justice League), but most superheroes are on their own. Superheroes do seem to be an "invention" of the Western countries and seem to reflect the structure of the society. Nowadays things are changing, also the rest of the world is experiencing a superhero hype and an Americanization with global brands like Mc Donald's or Starbucks coming from America. "And it's not just America - markets in Europe and Asia (especially China) have also embraced superheroes" (Berryhill, 2018). Why now a superhero in a Western style like Captain America? This could be explained with the following statement: "Through the years, comic book characters have addressed political, personal, and social issues, inspiring the American public along the way" (Invaluable, 2018). Superheroes deal often with political and social issues and were also inspired by actual events (Captain America was created in the Second World War, Green Lantern was inspired by a subway accident) (Invaluable, 2018). Superheroes therefore were never intended to exist in a parallel universe but they were inspired by real events and created to face the same problems as moral people do: War, 
terror, the evil, love and sacrifices. The Eastern societies also become more and more Westernized. It seems to be logical that also the idea of a Western superhero is embraced in the East. That hero deals with entities from the past, the present and the future. And in Ukraine, as the following chapter will show, there is a lot to deal with.

\section{COPING WITH THE PAST, THE PRESENT AND THE FUTURE}

In the comic, the foreword is about the nuclear accident at Chernobyl but it takes place in the present times. As we see the comic tries to build a bridge between the past and today. The Chernobyl nuclear accident took place in the biggest nuclear plant of the USSR (Perrineau, p. 4). "For millions of people on this planet, the explosion of the fourth reactor of the Chernobyl nuclear power plant on April 26, 1986 divided life into two parts: before and after" (accentuation by the author; Nesterenko, Nesterenko \& Yablokov, 2009, p. 1). Maybe this quote makes the paradox clear: Why would someone publish a comic in 2018 which refers to a nuclear catastrophe that happened 32 years ago? The nuclear accident is still very relevant for today's people in Ukraine. In 2019 for example Sergey Belyakov published a book with his experiences as a Liquidator in Chernobyl. He asks himself what would have happen when at that time the people would have had the communication tools of today (Belyakov, 2019, p. 3). The Chernobyl nuclear catastrophe still does play a role in the life of those who live in the territory of the nuclear cloud. "In 2018, the United Nations Scientific Committee on the Effects of Atomic Radiation (UNSCEAR) reported that the accident also was responsible for nearly 20,000 documented cases of thyroid cancer among individuals who were under 18 years of age at the time of the accident in the three affected countries including Belarus, Ukraine and the Russian Federation." (Nuclear Energy Institute, 2019). The consequences of the nuclear catastrophe are still present today: The individual faith of the people was changed and the faith of societies was changed. The comics promotional text starts with the following words: "Our world will never be the same again" (UKRMAN Homepage) To place the setting in reference to the nuclear accident is also rooted in urban legends still present today: Litash states that there are many myths about mutant people living in the closed zone around the contaminated city of Prypiat (Litash, 2018).

Above it was said that UKRMAN is made to be an inspiration for ordinary people and that superheroes are inspired by real events and cope 
with ordinary problems. How about UKRMAN? Why is the comic set in today's world dealing with the past?

Ukraine has some difficulties with its past. There seems to be a constant struggle in the country about the sovereignty of interpretation: Was the countries past defined by the Soviets (i.e. Russians) or by the country's own nation attempts? What consequences did the Soviet regime had and still has in the society? Ukrainian as a language was banned in the Russian Empire for a long time, the educated Ukrainians were expected to speak and write in Russian and Ukrainian literature and culture just existed in the shadows. "This denial of Ukraine's national distinctiveness had major implications for modern Russian and Ukrainian identities" (Yekelchyk, 2014). One has to understand that in Ukraine nation building is still an ongoing process. "In the twenty-three years since the Soviet collapse, the political elites in Russia and Ukraine learned to exploit the ambiguous sense of identity in both countries" (Yekelchyk, 2014). The Ukrainian identity is still in the making. The country has to decide their memory of history. After 2013, streets, places and cities named after Communists have been renamed. "Ukraine has changed the way it looks at the recent past, particularly the events [...] that were so controversial, painful, and remain in people`s memories" (Marples, 2013, p. 238). The above said struggle with the events of the past, the history that is still influencing the present and the nation building of Ukraine seem to be perfect to be portrayed in a comic. As it was shown above, most of the comics in Ukraine do refer to national historical events and personage. Ndalianis (2007, p. 1) sees the huge success of comics because of that relevance: "The crisis in global identity that followed the devastating events of September 112001 is frequently cited in the media as catalyst for the superhero's revived success." When identity is at stake, a superhero can bring calm into the storm. He becomes the figure of identity for many people. "Superheroes have never operated in a vacuum" (Ndalianis, 2007, p. 3) but they are rooted in the society and history and often have a message to tell. This message discussed above comes in UKRMAN with a strong national context, symbols and colors.

\section{THE MEANING OF COLORS AND SYMBOLS IN UKRMAN}

This chapter tries to answer the question: Why is it necessary to introduce yet another superhero? Do we not have enough superheroes in the world? It is no wonder that the Ukrainians tend to have their own superhero. In the chapter above it became clear that Ukraine struggles with its past. Ndaliani sees this as a perfect basis for introducing superheroes. 
"Whether conscious or unconscious, hero narratives give substance to certain ideological myths about the society they address (Ndaliani, 2007, p. 3).

On the cover and also on the homepage, UKRMAN is portrayed in a yellow-blue suit. He has no cape but a hood that is hiding his eyes.

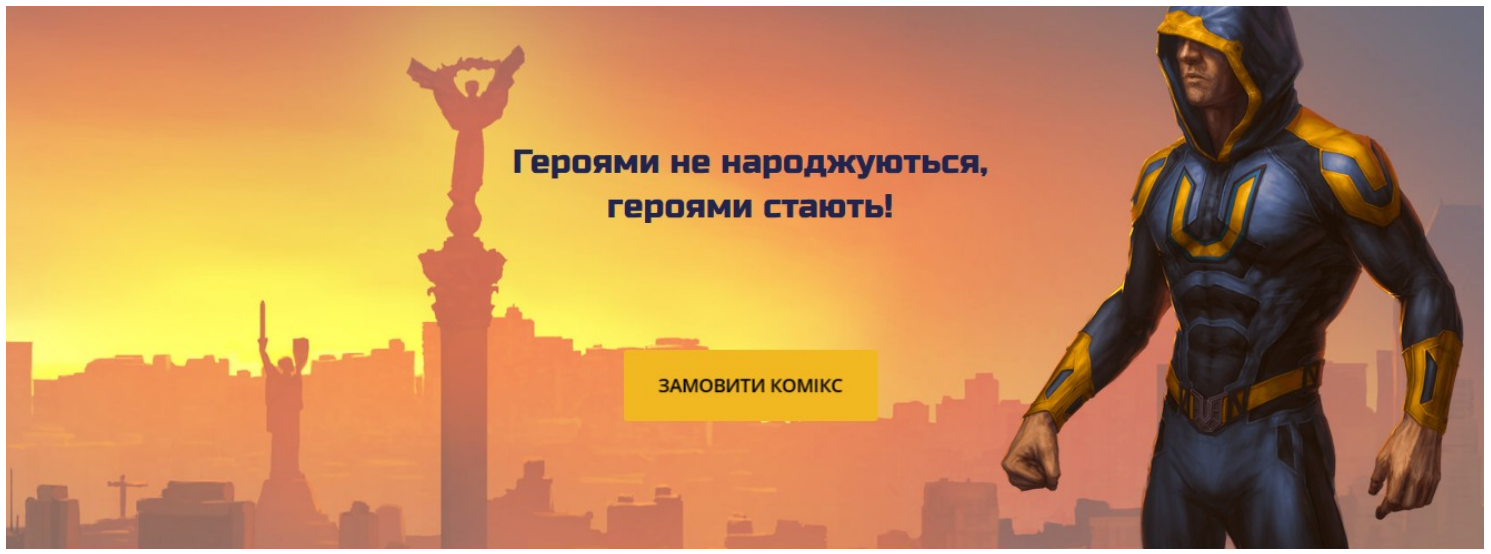

Fig. 2. UKRMAN Homepage [26.08.2020 $]^{1}$

The colors are the same as the Ukrainian flag: Yellow and blue. The "U" on the chest of UKRMAN looks similar to the trident of the Ukrainian herb.

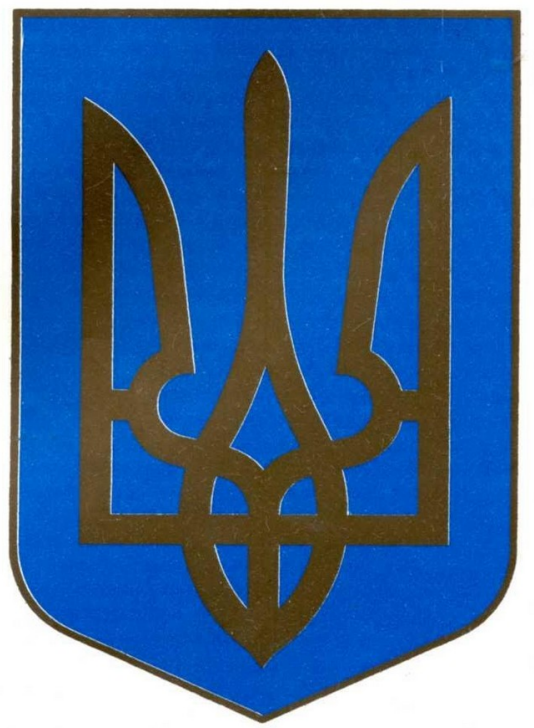

Fig. 3. Trident of Ukraine in the colors blue and yellow (Document Nr. 2137, 1992)

1 Heroes are not born, heroes are made. 
The history of Ukraine and the history of its national symbols is closely linked together and show the importance of a Ukrainian superhero who is portrayed in yellow and blue.

In August 1991, Ukraine became an independent state. The Soviet Union collapsed. The young state was in need to choose new national symbols. In 1992, as seen above in Document Nr. 2137, the Ukrainian State declared its new symbols: The Trident and the yellow and blue flag. But the implementation does not mean that all people suddenly feel represented by those symbols. "Ukraine's national flag, emblem and anthem have a long history and national status but have yet to become true national symbols “(Rukkas, 2012). In 2013, the so called „Euromaidan“ began in Kyiv after President Yanukovych refused to sign the Association Agreement with the European Union. The mostly young protestants were gathering together in the end of November 2013 leaving the Independence Square of Kyiv (Maidan Nezalezhnosti) just in June 2014. Numerous Ukrainian flags and coats of Arms could be seen at the Maidan in Kyiv and also throughout the whole country. "Those events fundamentally changed the attitude to state symbols." (Volynsky, 2019) To understand the importance of the national symbols for Ukrainians, Oleksandr Volynsky should be cited. He puts this into very emotional words: Thousands of flags of a free independent country, which is fighting and building its future and is striving to move away from a post-empire towards a community of democratic European states, are raised across Ukraine... By the way, the symbols of the European Union are also blue and yellow ,by an amazing coincidence." (Volynsky, 2019) So it can be seen that the national symbols became important after the Maidan in 2013. I think that it is no coincidence that UKRMAN has a very strong reference to the national symbols of Ukraine.

The strong national symbols and colors remind us about Captain America.

There are significant parallels also seen by some reviewers: UKRMAN does a lot look similar to Captain America (Myron, 2018). The muscles and the fact that one man is fighting for his country and for the good does also unite them. Although UKRMAN has no shield or other weapons or gadgets (just his fists), he also fights like Captain America. The strong reference to the national colors and even the initial letter of the country's name they are fighting for (Captain America has an " $\mathrm{A}$ " on his forehead and UKRMAN wears an "U" on his chest) are also obvious similarities. UKRMAN could be called "Captain Ukraine". 


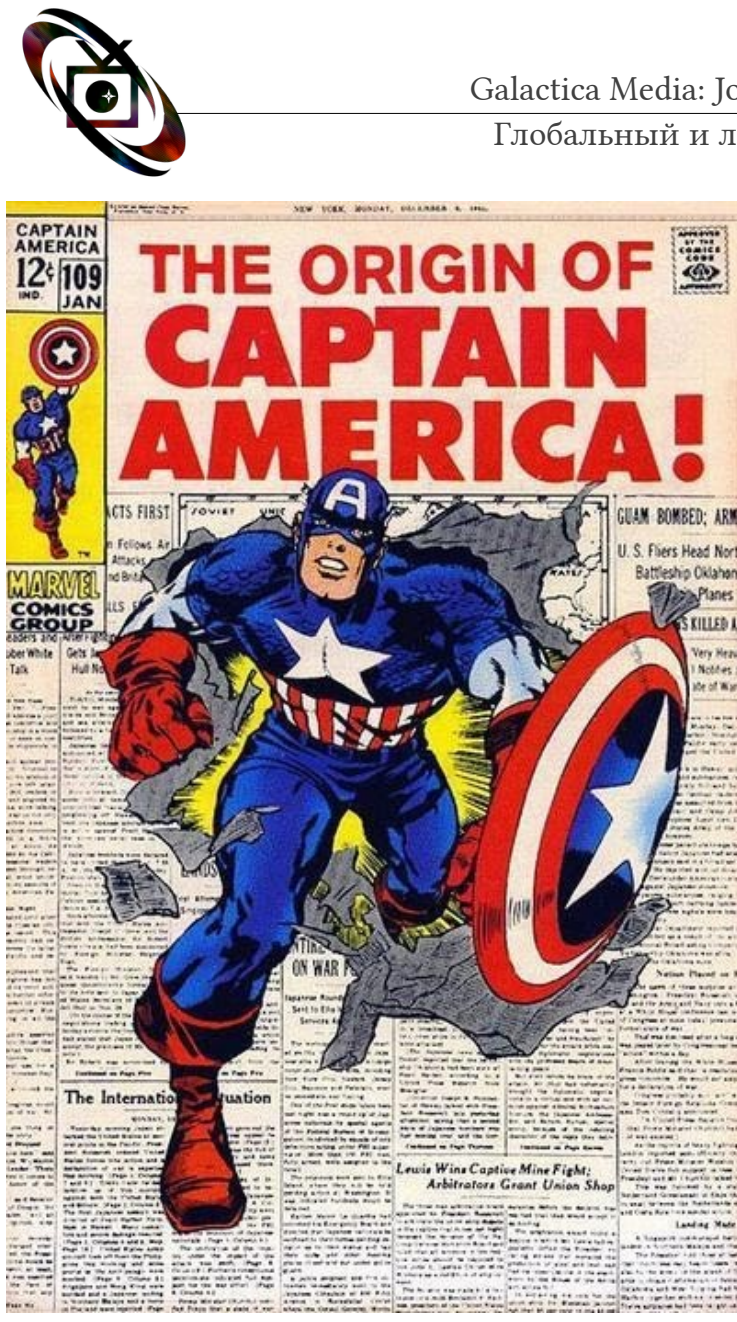

Fig .4. Cover of the comic Captain America \# 109 published in 1969 (Comics.org)

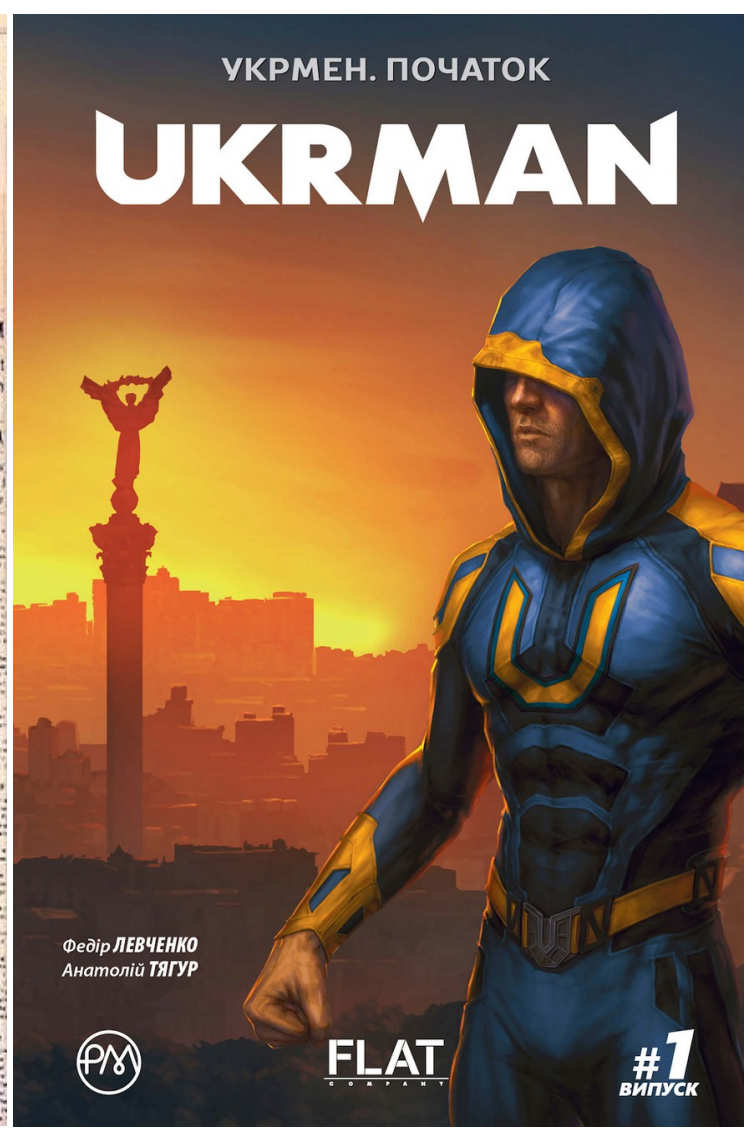

Fig. 5. The cover of the first issue of UKRMAN (ukrman.ua)

There are significant parallels also seen by some reviewers: UKRMAN does a lot look similar to Captain America (Myron, 2018). The muscles and the fact that one man is fighting for his country and for the good does also unite them. Although UKRMAN has no shield or other weapons or gadgets (just his fists), he also fights like Captain America. The strong reference to the national colors and even the initial letter of the country's name they are fighting for (Captain America has an "A" on his forehead and UKRMAN wears an " $U$ " on his chest) are also obvious similarities. UKRMAN could be called "Captain Ukraine".

The background on the cover (see Image 2) shows the city center of Kyiv with two very significant sights of Kyiv: The Statue of Independence (at the Independence Square) and the Motherland Monument are shown. The Statue of Independence are a symbol for the history of Ukraine since 1991. Symbolic for Soviet Times is the Motherland Monument (with its Museum of the Second World War). Interestingly, we can see that both Monuments are depicted as the symbols of Kyiv. This is not a coincidence. 
The authors could also have chosen other sights of Kyiv, as for example the St. Sophia Cathedral or the St. Andrew's Church. They chose the two Monuments standing for the Soviet history and the Independence of Ukraine. That structure seems to be logical: The comic combines both periods of time. It starts in Soviet times with the Chernobyl nuclear catastrophe and introduces UKRMAN as a superhero of today's Ukraine.

The obvious reference to Ukrainian symbols described above does not please some reviewers. The Blogger Myron says that in the comic there is an "open patriotic topic" (Myron, 2018). She states that the comic is "shouting in your face that it is Ukrainian" (Myron, 2018). This is definitely one consequence of the current situation in Ukraine: The fear of an external enemy has forced many people to feverishly sacralize national symbols, instantly untying the hands of a variety of fiery-eyed young men who are mutilating exhibitions with impunity, almost directly referring to "degenerate art"(Pitnyk \& Pitnyk, 2019). The national symbols and colors (that have to be defended in these times) seem to be overrepresented in the comic for obvious reasons: They are the symbols the nation is built on and they should be the symbols uniting all Ukrainians. UKRMAN has the mission not only to protect the country and promote the idea that everyone can be a hero but also of being the official superhero of Ukraine representing the moral and mentality of the country. Therefore, it is essential to have a look at the portrayal of UKRMAN and at his behavior.

\section{THE LOOK OF UKRMAN}

In UKRAMAN we see the duality of two men: Bohdan as a student and his alter ego UKRAMAN. Bohdan is a very muscular young man as most male superheroes are (for example Captain America, Bruce Wayne and Superman). Taylor criticized that ,hyper-masculine in superhero portrayal" (Taylor, 2007). Reyns (2018) criticizes that UKRMAN looks like an amalgamation of Superman and Captain America. But he is also introduced as a normal young man. He does not stand outside of society but he is a part of it, studying chemistry in Kyiv. Pitnyk and Pitnyk (2019) criticize that UKRMAN with his hood looks almost like the Assassins of the famous video game. 


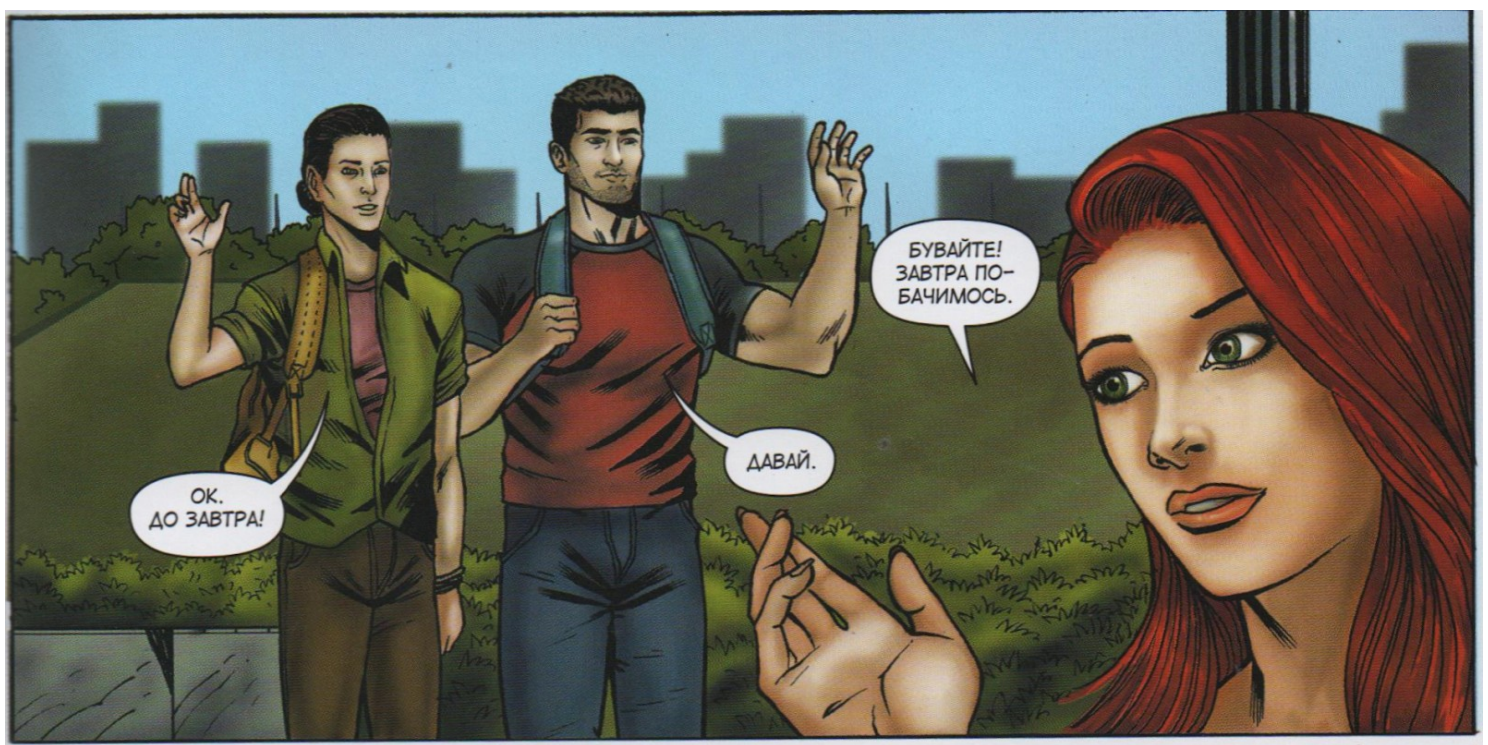

Fig. 6. Yurii, Bohdan (UKRMAN) and Zlata (Levchenko \& Tyahur, 2018, p. 15)

His friend Yurii, standing next to Bohdan, seems to be much skinnier and weaker. „Visually, superhero characters have a masculine stereotype body, which represent by well-developed muscles body, thereby increase the body size." (Putri, 2016, p. 163). The chosen way of portraying UKRMAN can therefore be defined as a usual way Superheroes are portrayed. Although the comic has the message that you don't need to have a suit to do good deeds, at least one has to be muscular.

Another fact seems to be the past of Bohdan: We know nothing about it. The short flashback where he rescues the son of his chemistry professor is also an episode from his student's days. There is no family introduced, he seems to live alone with his dog. That could intend that he has no family. His only friends introduced in the comic are Yurii and Zlata. In the first issue no past of the hero is published. Another stereotype of superheroes is probably not true for UKRMAN. „So if we look carefully all our heroes are basically men who have fallen from grace, they are not these perfect ideals" (Singh, 2017).

Most of the story takes place at night or in other dark rooms (like the laboratory of Khemikata). The fight between UKRMAN and the evil mutant takes also place at night (see image 7). 


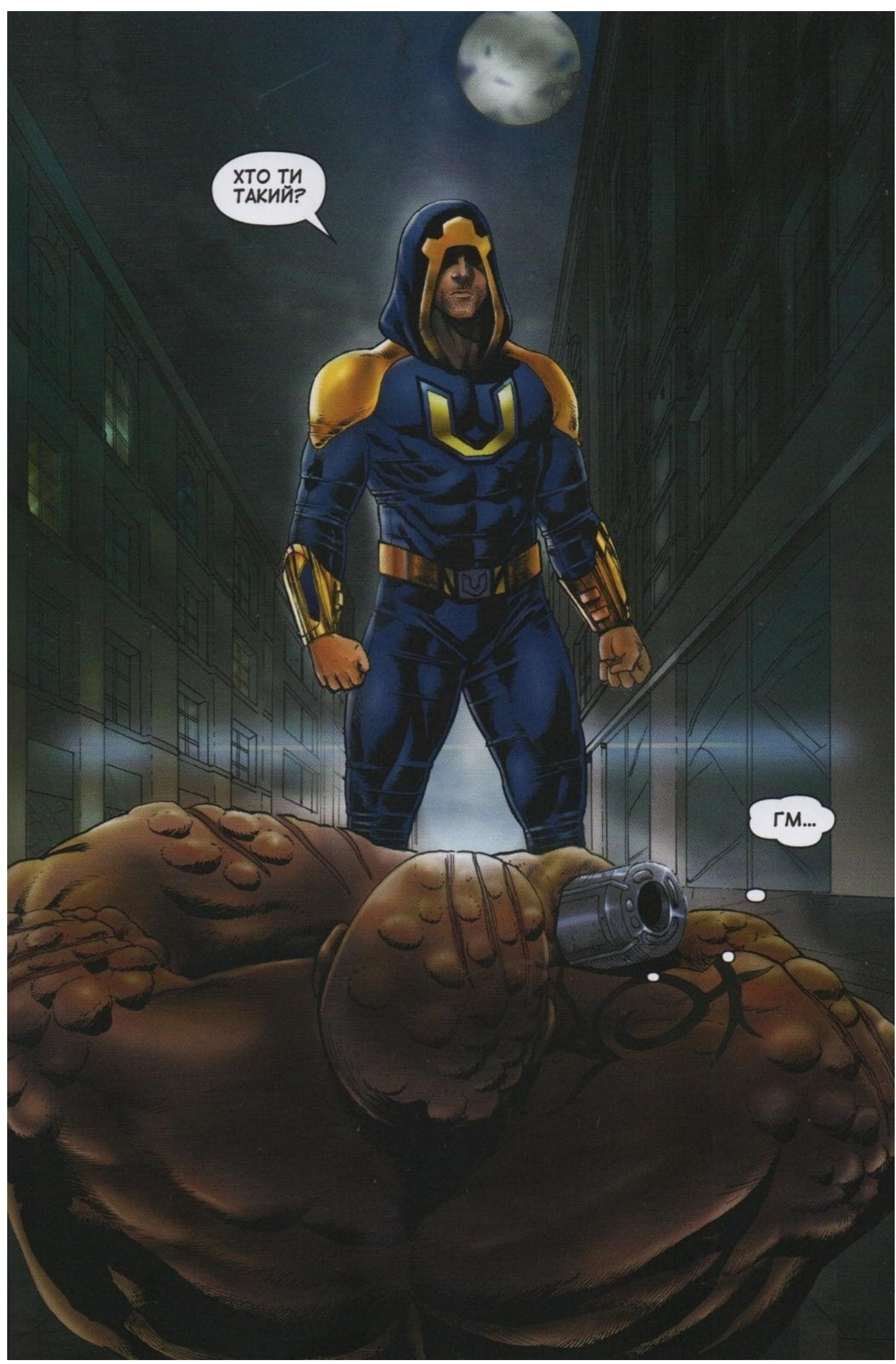

Fig. 7. Fight between UKRMAN and the evil mutant Biuce (Levchenko \& Tyahur, 2018, p. 32) 
Interestingly, some places of Kyiv are introduced in the comic and if you know the city well, you will definitely recognize streets and buildings. The Olympic stadium for example and the Velyka Vasylkivska Street next to it are obvious in the comic.

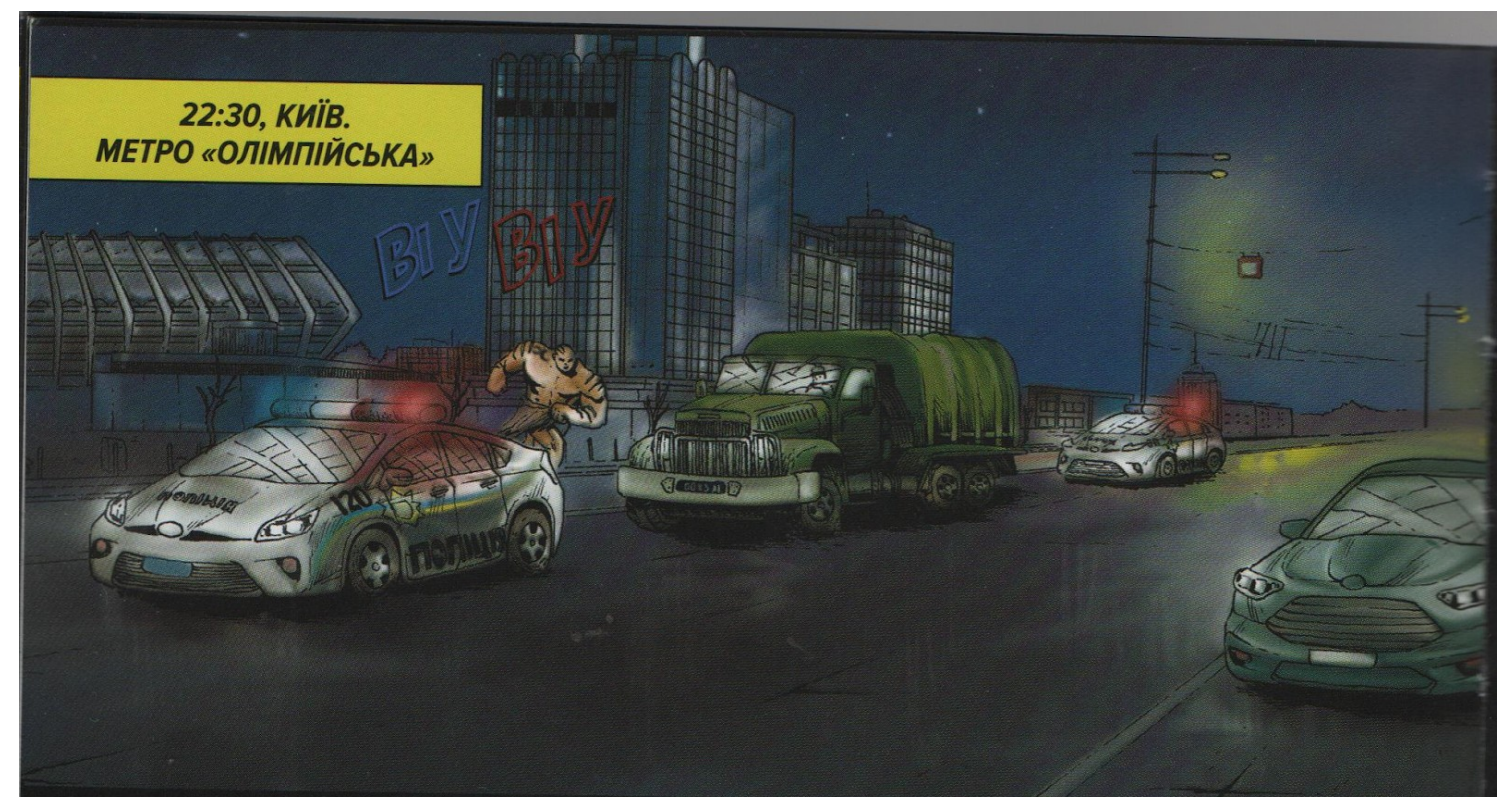

Fig. 8. The beginning of the fight with the evil mutant at the metro station "Olimpiiska" (Levchenko \& Tyahur, 2018, p. 28)

Myron (2018) criticizes that in the comic half of the city is empty that does not happen even in the evening in Kyiv. Reyns (2018) states that the city center of Kyiv looks almost like New York City and also the shown policemen and the major look very American.

\section{THE BEHAVIOUR OF UKRMAN}

UKRMAN seems to be the impersonated good in this world. He is portrayed as a good boy who tries to change the world staring with changing himself (Oliynyk, 2018, p. 24). His behavior reminds us of Batman: He refuses to kill (White 2019). UKRMAN does not fight to kill but to arrest the evil mutant and to make the streets and the city safer. To be the protector of the city is also very much like Batman. The creators set him a task: not only to demonstrate superpowers, but also to remain human in any difficult situation (Oliynyk ,2018, p. 24). Oliynyk sees a parallel between the portrayal of UKRMAN and Ukrainians these days: This is how they see the modern Ukrainian [...] a man of action. (Oliynyk, 2018, p. 24). 
When we look at the behavior of UKRMAN in the battle against the evil mutant, one is reminded not only of the behavior of Batman, but also of the one of Captain America in the 1930s comics (Reyns, 2018). UKRMAN gets into a fist fight with the evil mutant and at the end the villain is arrested. There is blood and scars but nothing serious. Some people die but they were not the main protagonists but some minor characters. The comic shows brutality very briefly but, in the end, the good forces win. The mutant is arrested and civil order is reinstructed.

\section{ADAPTATION OF THE UKRMAN-CHARAKTER IN OTHER MEDIA}

The project "UKRMAN" is an open project. The first comic issue was published in 2018 and can be bought in all major bookstores in the country. On the homepage (https://ukrman.ua) there is an announcement for artists to work together with the publishing house probably for other issues of the comic. But the character of UKRMAN does not finish here.

Interestingly the comic is not the only project where UKRMAN plays a major role. In the end of march 2020 on the official You Tube channel of UKRMAN there appeared a video of UKRMAN fighting the Corona virus.

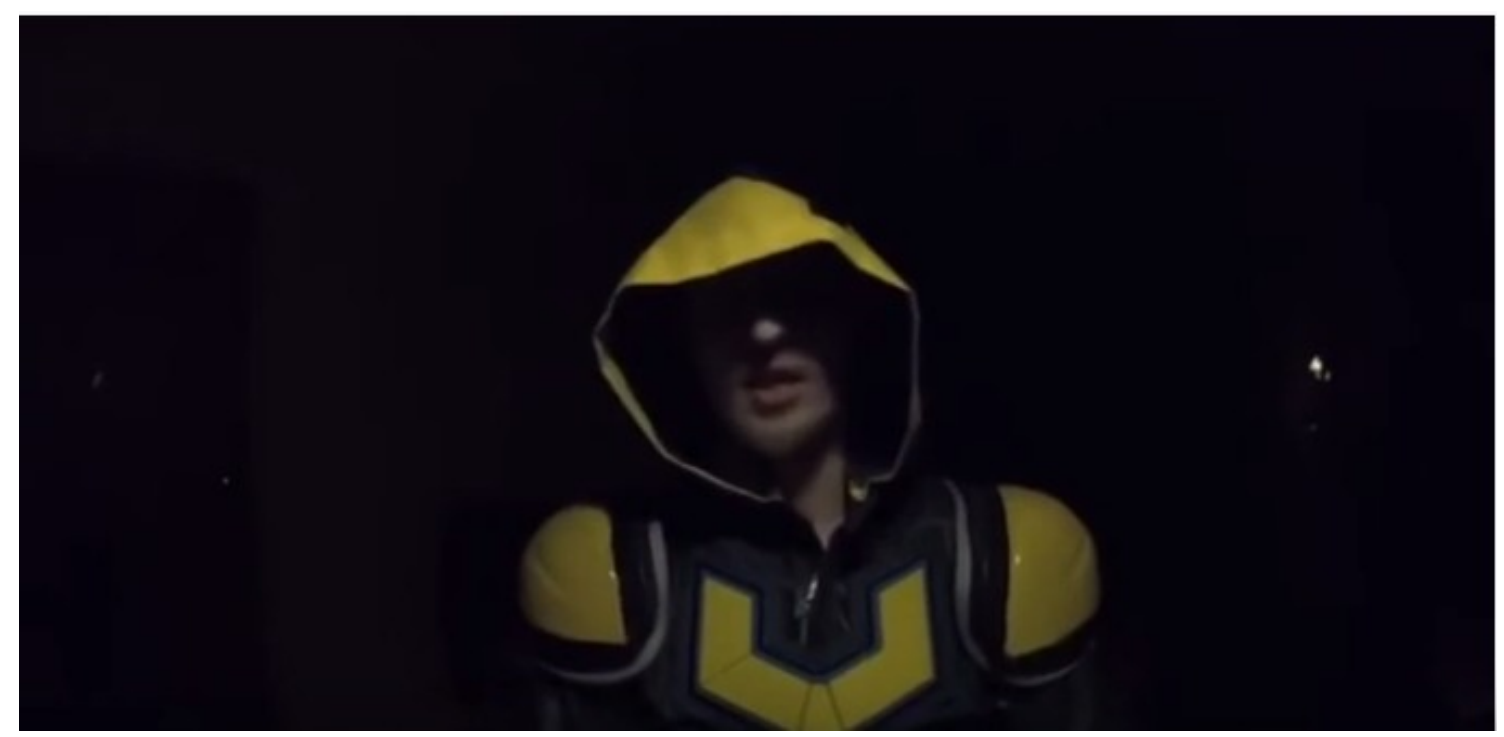

Fig. 9. UKRMAN vs. Corona Virus (You Tube 2020)

In the 2 Minute video, a man dressed in the UKRMAN suit talks to the camera. He begins with his profession and states that as a student of chemistry he has a lot to say about viruses and bacteria. In the video, the man addresses the audience saying that the current situation is critical: Everybody has to do everything in his or her power to stop the virus. To 
reduce contact with other people, to stay at home and to look out for each other is crucial in these times. "Now everybody of us has to be a superhero". He says that message twice in the short video. The man is certain that mankind will win against the virus "but everything depends on us now!"

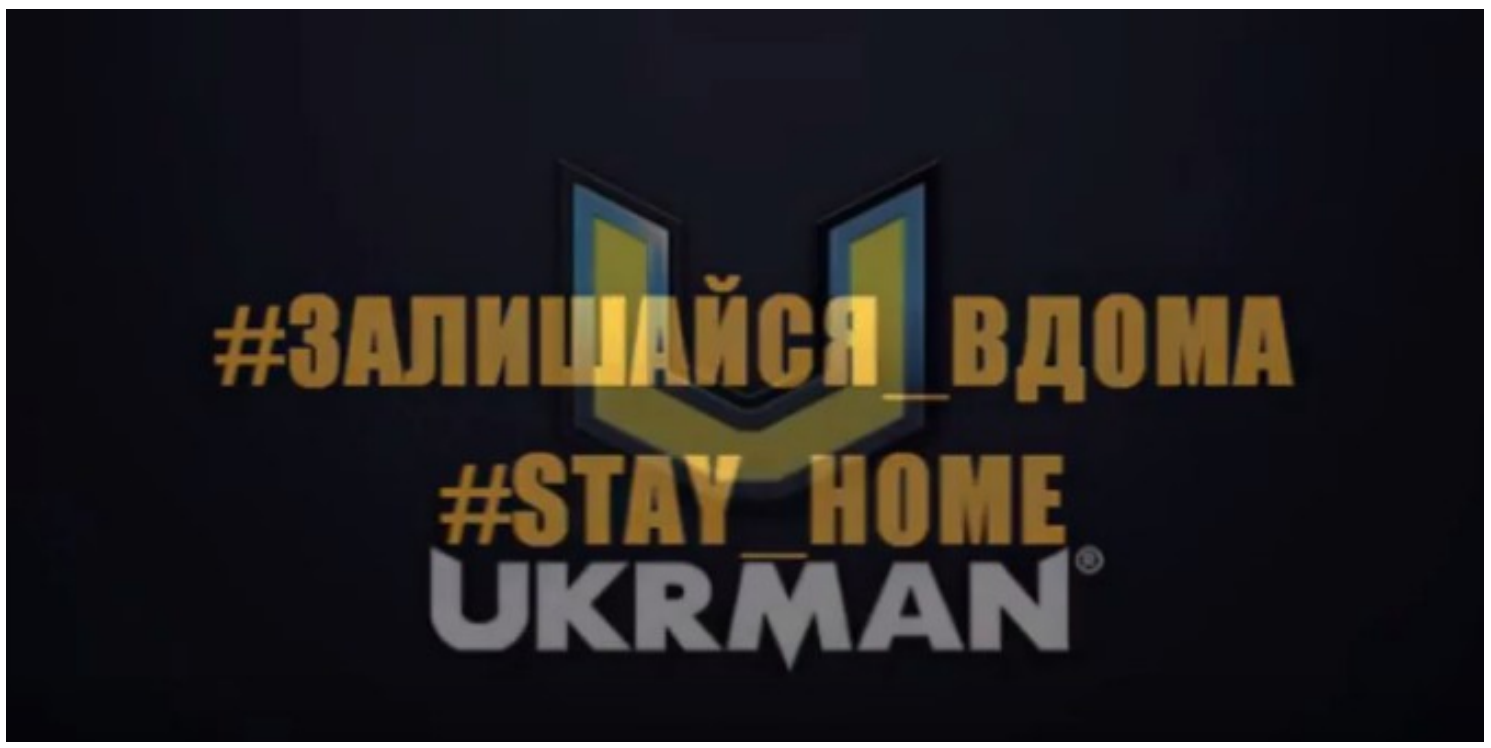

Fig. 10. UKRMAN tells the audience to stay home. (You Tube 2020).

The figure of UKRMAN is used here to spread a message: The reallife action hero appears in front of a camera to tell people how to behave during the Corona crisis in spring 2020. The message initiated in the comic and also spread via the homepage and in the marketing campaign helps to set up this message. Also, in the battle with the Corona virus, everybody is needed. By the 30.08.2020, the video just had 68 views.

Reyns states that the special role UKRMAN plays in Ukrainian comic is the fact that there was a huge media campaign, the comic was widely reviewed by many journals and there is even the plan to do a cartoon about it (Reyns, 2018). That also caused a widely reception of the comic as a literal genre and of the figure of UKRMAN.

\section{CONCLUSION}

With UKRMAN we saw the actualization of the superhero character in the 21st century. The comic combines two periods of time: The Soviet era and today's independent Ukraine. It sets up the first superhero of Ukraine. Although that superhero has a lot in common with already existing superheroes of America, it can be taken as the attempt to create a hero that unites Ukraine and popularizes the national color, flag and symbols. 
Anatoliy and Kateryna Pitnyk (2019) state that superheroes usually should represent the whole country. UKRMAN is an attempt to implement an ordinary man, not heroes from the past like the Cossacks, to become an example for everybody. In America they have Batman and Spiderman, but our heroes, they are real, taken from real life (Lvivskyi Portal, 2015). Reyns (2018) states that the comic could also have been released in the USA. The main hero is a noble one, the city, personage and the whole scenery (hero with superpowers fights an evil mutant, at the end the good forces win) looks very much like in the Captain America comics of the 1930s.

Yet there is room for improvement. The message of the comic seemed to be too obvious and the biggest point of critique is the plot (Myron, 2018; Reyns, 2018). The words of Myron (2018) do summarize the first issue of UKRMAN very well: "Yes, 'UKRMAN' is sometimes raw, naive, written off from other works, but it may have a good future." Also, the obvious national symbols and colors were criticized. "The main thing is not to delve deeper into the topic of patriotism than necessary, because people like me, who read for the sake of the plot and characters, and not the national idea, it only scares." (Myron, 2018) On the other hand side the comic was always a literal genre to transport messages and bring history and national identity in discussion.

Was it necessary to create yet another superhero? After the analysis done here one can state: Yes. Superheroes "responds in a dynamic way to various challenges and social needs" (Ndaliani, 2007, p. 3) and UKRMAN does that in a good way: The implemented message of the comic is used to warn people before the Corona virus and to state the message that everyone can be a hero. There is probably no message as powerful as this one.

\section{References}

Belyakov, S. (2019). Liquidator. A Chernobyl Story. Singapore: World Scientific.

Berryhill, A. (2018). Why are People So Obsessed with Superhero Movies? Retrieved from INTELLECTUAL TAKEOUT. https://www.intellectualtakeout.org/article/whyare-people-so-obsessed-superhero-movies/

Burianyk, M. (2015). Ukrainian comics of the 1990s. Retrieved from https://mburianyk.wordpress.com/2015/08/02/ukrainian-comics-of-the-1990s/ [30.08.2020].

Comics. Org. Captain America \#109. Retrieved from https://www.comics.org/issue/ $22463 /$ cover/4/ 
Document Nr. 2137 (1992). Derzhavniy Herb Ukrayiny (National Coat of Arms of Ukraine). Retrieved from https://zakon.rada.gov.ua/cgi-bin/laws/main.cgi? nreg $=2137 \% \mathrm{E} 0-12$

Facebook UKRMAN. (2020). Information about the page. Retrieved from https://www.facebook.com/ukrman.ua/

Gavrishova, A. (2015). Avtor komiksov Igor Baranko: "Ukrainskogo kak takovogo sdelano malo - dyry vo vsekh zhanrakh i oblastyakh". (Comic author Igor Baranko: In Ukrainian something like that has been done not many times - holes in all genres and areas) Retrieved from PLATFORMA. https://reinvent.platfor.ma/ igor-baranko/

Invaluable. (2018). The Inspiration Behind Iconic Comic Book Characters. Retrieved from https://www.invaluable.com/blog/comic-book-characters/

Kvitka, A. (2019). Nash Kapitan Amerika. Istoriya ukrayinskoho komiksu. (Our Captain America. The history of Ukrainian comics). Retrieved from https://bit.ua/ 2019/12/comics/?fbclid=IwAR0f26Be3tgDRl6hlszkqg_1vWqP6UWgRWLXEQXuSIcTjZOTpo7BgyRUMAs

Lange, A. (2017). Daohopak - eine Comicreihe über Kosaken als Teil der Identitätsbildung der Ukraine. In B. Dolle-Weinkauff (Ed.), Geschichte im Comic (pp. 157170). Berlin: Bachmann Verlag.

Levchenko, F. \& Tyahur, A. (2018). UKRMAN. Pochatok. Kyiv: Ridna Mova.

Litash, N. (2018). Ukrman, abo Nichoho cobi komiks pro superheroya. (Ukrman, or Wow a comic about a superhero). Oblast Libarary of Luhansk. Retrieved from http:// library.lg.ua/uk/pearl/723

Lvivskyi Portal. (2015). Vidomi lvivyany poznayiomyly ditey uchastnykiv ATO z ukrayinskymy superheroyamy. (Well known citizens of Lviv got to know children of ATO participants with superheroes). Retrieved from https://portal.lviv.ua/news/2015/09/14/vidomi-lviv-yani-poznayomili-ditey-uchasnikiv-ato-zukrayinskimi-supergeroyami

Markus, H. R. \& Kitayama, S. (1991). Culture and the self: Implications for cognition, emotion, and motivation. Psychological review, 98(2), 224-253. Doi: 10.1037/0033-295X.98.2.224

Marples, D. (2013). Heroes and Villains: Creating National History in Contemporary Ukraine. Budapest: Central European University Press.

Matychak, T. (2019). Why Are Cossacks Key to Understanding the Ukrainian Nation? Retrieved from UKRAINE WORLD. https:/ukraineworld.org/articles/ukraine-explained/why-are-cossacks-key-understanding-ukrainian-nation

Myron. (2018). UKRMAN I filosofskyi pidkhid. (A Philosophical approach to UKRMAN). Retrieved from https://myronthinks.blogspot.com/2018/05/ukrman.html

Ndalianis, A. (2007). Do we need another Hero? In W. Haslem; A. Ndalianis; C. Mackie (Eds.) Super/heroes: From Hercules to Superman. (pp. 1-10). New Academia Publishing, LLC. 
Nesterenko A., Nesterenko, V. \& Yablokov, A. (2009). Introduction: The Difficult Truth about Chernobyl. In A. Yablokov; V. Nesterenko; A. Nesterenko; J. ShermanNevinger (Eds.), Chernobyl. Consequences of the Catastrophe for People and the Environment, Volume 1181. (pp. 1-4). New York City: Blackwell Publishing.

Nuclear Energy Institute (2019). Chernobyl Accident and Its Consequences. Washington D.C. Retrieved from https://www.nei.org/resources/fact-sheets/chernobyl-accident-and-its-consequences

Oliynyk, L. (2018). Suchasna literaturna skrynka (Modern literature box). 3rd Issue. Odessa: Oblast Library for Young Readers.

Perrineau, A. (2017). The Chernobyl Disaster: The Nuclear Catastrophe and its Devastating Effects. 50 Minutes History. LEMAITRE: Brussels.

Pitnyk, A. \& Pitnyk, S. (2019). Kvantovyy strybok Kapitana Ukrayiny: koly chekaty na zolotu dobu ukrayinskykh komiksiv. (Quantum leap of the Captain of Ukraine: when to wait for the golden age of Ukrainian comics). Retrieved from https:// www.chytomo.com/kvantovyj-strybok-kapitana-ukrainy-koly-chekaty-nazolotu-dobu-ukrainskykh-komiksiv

Putri, R. (2016). Ideal Superhero Body: Under the Influence of Western and Asian Masculinity. International fournal of Multidisciplinary Thought, 5(5), 163-174 (2016).

Radio Svoboda (2018): “UKRMAN” ta inshi superheroyi. Yak rozvyvayetsya ukrayinska industriya komiksiv. (UKRMAN and other superheroes. How the Ukrainian comics industry is developing). Retrieved from https://www.radiosvoboda.org/ a/yak-rozvyvayetsya-ukrayinska-industriya-komiksiv/29 641 200.html

Reynolds, R. (1992). Super Heroes: A Modern Mythology. Mississippi: University Press of Mississippi.

Reyns, A. (2018). "Bez sala i horilki" - vpechatlenie ot komiksa "Ukrman" ("Without bacon fat and wodka" - impression of the comic 'Ukrman'). Retrieved from https://dtf.ru/read/98 484-bez-sala-i-gorilki-vpechatlenie-ot-komiksa-ukrmen [30.08.2020].

Romagnoli, A. \& Pagnucci, G. (2013). Enter the Superheroes: American Values, Culture, and the Canon of Superhero Literature. Lanham: Scarecrow Press.

Rosenberg, R. \& Coogan, P. (2013). What is a Superhero? OUP USA.

Rukkas, A. (2012). Symbols of Independence. Ukrainian Week. Retrieved from https:// ukrainianweek.com/History/54532

Singh, H. (2017). The Superhero Phenomenon. Retrieved from MEDIUM. https://medium.com/applaudience/the-superhero-phenomenon-9eeefe 55e $5 \mathrm{da}$

Sodomora, Kh. (2016). Hryby, viyna I dytyacha ilyustraciya. (Mushrooms, war and children's illustrations). Retrieved from ZhuBooks. https://zhutext.wordpress.com/2016/09/25/

State Intellectual Property Service of Ukraine (2014). Bulletin Nr. 34. Kyiv. 
Taylor, A. (2007). He's gotta be strong, and he's gotta be fast, and he's gotta be larger than life': Investigating the engendered superhero body. The fournal of Popular Culture, 40(2), 344-360.

UKRMAN Homepage. (2020). Retrieved from https://ukrman.ua/

Volynsky, O. (2019). Twenty-five important facts about Ukrainian flag. Retrieved from UKRINFORM. https://www.ukrinform.net/rubric-polytics/2 765 635-twentyfiveimportant-facts-about-ukrainian-flag.html

White, M. (2019). Why We Relate to Batman. Batman's moral inconsistency may be another reason he seems so familiar to us. Retrieved from https://www.psychologytoday.com/us/blog/maybe-its-just-me/201 912/why-we-relate-batman

Yakaboo. (2019). Ne „Betmenom “yedynym: zaproshuyemo u svit komiksiv. (Batman is not the only one: we invite you to the world of comics.) Retrieved from https:// blog.yakaboo.ua/den-komiksiv/?fbclid=IwAR1zrm62yOjt0H6iBjXaH8TZLwL9ygYKaF32rSw8Np8271_CoPigkuu6fW4

Yekelchyk, S. (2014). History strikes back: Ukraine's past and the current crisis. Retrieved from OUP. https://blog.oup.com/2014/05/ukraine-history-current-crisis/

You Tube channel of UKRMAN. (2020). UKRMAN vs. Corona Virus. Retrieved from https://www.youtube.com/watch?v=wCNeoMiAsU4

\section{Список литературы}

Belyakov, S. (2019). Liquidator. A Chernobyl Story. Singapore: World Scientific.

Berryhill, A. (2018). Why are People So Obsessed with Superhero Movies? Retrieved from INTELLECTUAL TAKEOUT. https://www.intellectualtakeout.org/article/whyare-people-so-obsessed-superhero-movies/

Burianyk, M. (2015). Ukrainian comics of the 1990s. Retrieved from https://mburianyk.wordpress.com/2015/08/02/ukrainian-comics-of-the-1990s/ [30.08.2020].

Comics. Org. Captain America \#109. Retrieved from https://www.comics.org/issue/ $22463 /$ cover/4/

Document Nr. 2137 (1992). Derzhavniy Herb Ukrayiny (National Coat of Arms of Ukraine). Retrieved from https://zakon.rada.gov.ua/cgi-bin/laws/main.cgi? nreg $=2137 \% \mathrm{E} 0-12$

Facebook UKRMAN. (2020). Information about the page. Retrieved from https://www.facebook.com/ukrman.ua/

Gavrishova, A. (2015). Avtor komiksov Igor Baranko: "Ukrainskogo kak takovogo sdelano malo - dyry vo vsekh zhanrakh i oblastyakh". (Comic author Igor Baranko: In Ukrainian something like that has been done not many times - holes in all genres and areas) Retrieved from PLATFORMA. https://reinvent.platfor.ma/ igor-baranko/ 
Invaluable. (2018). The Inspiration Behind Iconic Comic Book Characters. Retrieved from https://www.invaluable.com/blog/comic-book-characters/

Kvitka, A. (2019). Nash Kapitan Amerika. Istoriya ukrayinskoho komiksu. (Our Captain America. The history of Ukrainian comics). Retrieved from https://bit.ua/ 2019/12/comics/?fbclid=IwAR0f26Be3tgDRl6hlszkqg_1vWqP6UWgRWLXEQXuSIcTjZOTpo7BgyRUMAs

Lange, A. (2017). Daohopak - eine Comicreihe über Kosaken als Teil der Identitätsbildung der Ukraine. In B. Dolle-Weinkauff (Ed.), Geschichte im Comic (pp. 157170). Berlin: Bachmann Verlag.

Levchenko, F. \& Tyahur, A. (2018). UKRMAN. Pochatok. Kyiv: Ridna Mova.

Litash, N. (2018). Ukrman, abo Nichoho cobi komiks pro superheroya. (Ukrman, or Wow a comic about a superhero). Oblast Libarary of Luhansk. Retrieved from http:// library.lg.ua/uk/pearl/723

Lvivskyi Portal. (2015). Vidomi lvivyany poznayiomyly ditey uchastnykiv ATO z ukrayinskymy superheroyamy. (Well known citizens of Lviv got to know children of ATO participants with superheroes). Retrieved from https://portal.lviv.ua/news/2015/09/14/vidomi-lviv-yani-poznayomili-ditey-uchasnikiv-ato-zukrayinskimi-supergeroyami

Markus, H. R. \& Kitayama, S. (1991). Culture and the self: Implications for cognition, emotion, and motivation. Psychological review, 98(2), 224-253. Doi: 10.1037/0033-295X.98.2.224

Marples, D. (2013). Heroes and Villains: Creating National History in Contemporary Ukraine. Budapest: Central European University Press.

Matychak, T. (2019). Why Are Cossacks Key to Understanding the Ukrainian Nation? Retrieved from UKRAINE WORLD. https:/ukraineworld.org/articles/ukraine-explained/why-are-cossacks-key-understanding-ukrainian-nation

Myron. (2018). UKRMAN I filosofskyi pidkhid. (A Philosophical approach to UKRMAN). Retrieved from https://myronthinks.blogspot.com/2018/05/ukrman.html

Ndalianis, A. (2007). Do we need another Hero? In W. Haslem; A. Ndalianis; C. Mackie (Eds.) Super/heroes: From Hercules to Superman. (pp. 1-10). New Academia Publishing, LLC.

Nesterenko A., Nesterenko, V. \& Yablokov, A. (2009). Introduction: The Difficult Truth about Chernobyl. In A. Yablokov; V. Nesterenko; A. Nesterenko; J. ShermanNevinger (Eds.), Chernobyl. Consequences of the Catastrophe for People and the Environment, Volume 1181. (pp. 1-4). New York City: Blackwell Publishing.

Nuclear Energy Institute (2019). Chernobyl Accident and Its Consequences. Washington D.C. Retrieved from https://www.nei.org/resources/fact-sheets/chernobyl-accident-and-its-consequences

Oliynyk, L. (2018). Suchasna literaturna skrynka (Modern literature box). 3rd Issue. Odessa: Oblast Library for Young Readers. 
Perrineau, A. (2017). The Chernobyl Disaster: The Nuclear Catastrophe and its Devastating Effects. 50 Minutes History. LEMAITRE: Brussels.

Pitnyk, A. \& Pitnyk, S. (2019). Kvantovyy strybok Kapitana Ukrayiny: koly chekaty na zolotu dobu ukrayinskykh komiksiv. (Quantum leap of the Captain of Ukraine: when to wait for the golden age of Ukrainian comics). Retrieved from https:// www.chytomo.com/kvantovyj-strybok-kapitana-ukrainy-koly-chekaty-nazolotu-dobu-ukrainskykh-komiksiv

Putri, R. (2016). Ideal Superhero Body: Under the Influence of Western and Asian Masculinity. International Journal of Multidisciplinary Thought, 5(5), 163-174 (2016).

Radio Svoboda (2018): “UKRMAN” ta inshi superheroyi. Yak rozvyvayetsya ukrayinska industriya komiksiv. (UKRMAN and other superheroes. How the Ukrainian comics industry is developing). Retrieved from https://www.radiosvoboda.org/ a/yak-rozvyvayetsya-ukrayinska-industriya-komiksiv/29 641 200.html

Reynolds, R. (1992). Super Heroes: A Modern Mythology. Mississippi: University Press of Mississippi.

Reyns, A. (2018). "Bez sala i horilki” - vpechatlenie ot komiksa "Ukrman" ("Without bacon fat and wodka" - impression of the comic 'Ukrman'). Retrieved from https://dtf.ru/read/98 484-bez-sala-i-gorilki-vpechatlenie-ot-komiksa-ukrmen [30.08.2020].

Romagnoli, A. \& Pagnucci, G. (2013). Enter the Superheroes: American Values, Culture, and the Canon of Superhero Literature. Lanham: Scarecrow Press.

Rosenberg, R. \& Coogan, P. (2013). What is a Superhero? OUP USA.

Rukkas, A. (2012). Symbols of Independence. Ukrainian Week. Retrieved from https:// ukrainianweek.com/History/54 532

Singh, H. (2017). The Superhero Phenomenon. Retrieved from MEDIUM. https://medium.com/applaudience/the-superhero-phenomenon-9eeefe $55 \mathrm{e} 5 \mathrm{da}$

Sodomora, Kh. (2016). Hryby, viyna I dytyacha ilyustraciya. (Mushrooms, war and children's illustrations). Retrieved from ZhuBooks. https://zhutext.wordpress.com/2016/09/25/

State Intellectual Property Service of Ukraine (2014). Bulletin Nr. 34. Kyiv.

Taylor, A. (2007). He's gotta be strong, and he's gotta be fast, and he's gotta be larger than life': Investigating the engendered superhero body. The fournal of Popular Culture, 40(2), 344-360.

UKRMAN Homepage. (2020). Retrieved from https://ukrman.ua/

Volynsky, O. (2019). Twenty-five important facts about Ukrainian flag. Retrieved from UKRINFORM. https://www.ukrinform.net/rubric-polytics/2 765 635-twentyfiveimportant-facts-about-ukrainian-flag.html

White, M. (2019). Why We Relate to Batman. Batman's moral inconsistency may be another reason he seems so familiar to us. Retrieved from https://www.psychologytoday.com/us/blog/maybe-its-just-me/201 912/why-we-relate-batman 
Yakaboo. (2019). Ne „Betmenom“ yedynym: zaproshuyemo u svit komiksiv. (Batman is not the only one: we invite you to the world of comics.) Retrieved from https:// blog.yakaboo.ua/den-komiksiv/?fbclid=IwAR1zrm62yOjt0H6iBjXaH8TZLwL9ygYKaF32rSw8Np8271_CoPigkuu6fW4

Yekelchyk, S. (2014). History strikes back: Ukraine's past and the current crisis. Retrieved from OUP. https://blog.oup.com/2014/05/ukraine-history-current-crisis/

You Tube channel of UKRMAN. (2020). UKRMAN vs. Corona Virus. Retrieved from https://www.youtube.com/watch?v=wCNeoMiAsU4 